\title{
Analysis of Wholesale Industry efficiency in Liaoning Province -- Based on DEA model
}

\author{
Qingman $\mathrm{Li}^{1}$, Xiuli Yan ${ }^{* 1}$ \\ ${ }^{1}$ Bohai University School of Management Liaoning, Jinzhou, China
}

\begin{abstract}
Based on DEA model, the wholesale efficiency of 14 cities in Liaoning province was measured. From the perspective of input and output, the wholesale efficiency of each city in Liaoning Province was systematically studied to evaluate the development of the wholesale industry in Liaoning Province. The results show that the wholesale efficiency in Liaoning province is generally low, but the returns to scale are increasing. The efficiency level varies greatly among different cities, and the reasons for non-DEA effective wholesale investment in different cities are different.
\end{abstract}

\section{Introduction}

At present, the wholesale industry at home and abroad has occupied a dominant position in the industrial chain of various industries and fields, and has played a key role in controlling the market, determining production and influencing consumption. With the increasing role of the wholesale industry in the national economy and the increasing contribution rate to the national economic growth, it has begun to become a leading industry guiding production and consumption. The report to the 19th National Congress of the communist Party of China (CPC) pointed out that China's economy has shifted from a stage of rapid growth to a stage of high-quality development, and is at a crucial stage of transforming the growth model, optimizing the economic structure, and transforming the driving force for growth. The building of a modernized economy is an urgent requirement for crossing the threshold and a strategic goal of China's development. Its frequent mention of consumption, including "in the highend consumption, innovation, leading, green low carbon, sharing economy, modern supply chain, services, and other fields to cultivate new growth points of human capital, forming new momentum," "perfect promote consumption systems and mechanisms, strengthen the basic role of consumption to economic development" oppose extravagance and waste and unreasonable consumption, etc. Therefore, it is of great significance for the development of wholesale industry and the overall healthy development of national economy to objectively evaluate the efficiency of China's wholesale industry, identify the causes of low investment efficiency, and find out the positive countermeasures.

Ye Meng, Zhu Heliang, and Sun Peng (2017) [1] took the panel data of 9 first-level subdivided industry enterprises in wholesale and retail above quota from 2008 to 2015 as samples, using the nonparametric estimation of
DEA - Malmquist index method, analysis, 2008-2015, wholesaling 9 niche business enterprise total factor productivity average negative state, retail 9 niche business enterprise total factor productivity average positive state. Chen hua (2018)[2] calculated and compared the wholesale industry in 31 provinces and municipalities and autonomous regions from 2007 to 2016 by using the super-efficiency DEA model. The research results showed that :(1) the growth of China's wholesale industry at the present stage is not caused by technical efficiency, and the low efficiency operation problem is relatively prominent. (2) The spatial "block" effect of the input-output efficiency of the wholesale industry in the three economic zones, eight economic zones and 31 provinces and municipalities (autonomous regions) is prominent, and there are obvious spatial differences. Cao Jun (2014) [3] used DEA method to analyze and evaluate the operating efficiency of China's wholesale and retail industry in 2006-2011, and the results showed that from 2006 to 2011, under the influence of the macroeconomic situation, the operating efficiency of China's wholesale and retail industry basically presented changes of "V" or "W". At present, there are relatively few studies on the efficiency of wholesale industry in China, and the research conclusions are different. In order to better evaluate the efficiency of regional wholesale industry, this paper uses DEA model to systematically study the operating efficiency of wholesale industry in liaoning province from the perspective of input and output, so as to evaluate the development status of liaoning province's wholesale industry.

\section{Research methods and data description}

\subsection{Research methods}

Efficiency refers to the comparative relationship between

*Corresponding author: 1498326642@qq.com 
input and output or cost and income in production activities, mainly including technical efficiency and scale efficiency. Technical efficiency reflects the ability of the evaluated object to obtain the maximum output in the case of a given input, while scale efficiency reflects whether the evaluated object operates under the most appropriate investment scale. Data envelopment analysis (DEA) is a method that evaluates the relative efficiency of the same type of unit (hereinafter referred to as decision-making unit) according to multi-index input and multi-index output. It is used to deal with multi-objective decisionmaking problems. The commonly used DEA models are CCR model and BCC model. The CCR model can only describe the technical efficiency, while the BCC model can simultaneously describe the comprehensive technical efficiency, pure technical efficiency and scale efficiency. DEA model has two types: input-oriented and outputoriented. Input-oriented refers to the study of efficiency from the perspective of input, that is, how to reduce input as much as possible when output remains unchanged, and output-oriented studies from the perspective of output. This study calculates and analyzes the wholesale efficiency of 14 cities in Liaoning Province. Since output is difficult to control and each city is not in the optimal scale stage, this study is based on the input-oriented BCC model.

\subsection{Indicators and data description}

\subsubsection{Index selection}

Manpower input was selected as the input index, which was expressed by year-end employees of the wholesale industry; Capital input, expressed in terms of wholesale fixed capital investment. Due to no end of wholesaling practitioners in statistical yearbook of specific data, draw lessons from Zhao Xia, chang-song wan, xuan hongyan (2018) [4] the estimation methods, namely regional circulation industry divisions in various areas of the whole society employment $=$ total employment $\mathrm{x}$ (regional circulation of urban employment/regional towns, total employment). The total number of employment in the wholesale industry in each region $=$ the total number of employment in each region $\times$ (the number of employment in the wholesale industry in each region/the total number of employment in each region). Main business income and Main business profit are selected to represent the output level of the wholesale industry. Variable description statistics are shown in Table 1.

Table1. Variable description statistics

\begin{tabular}{|l|l|l|}
\hline & \multicolumn{1}{|c|}{ variable } & \multicolumn{1}{c|}{ Variable description } \\
\hline \multirow{3}{*}{$\begin{array}{l}\text { Input } \\
\text { indicators }\end{array}$} & Manpower Input & $\begin{array}{l}\text { Wholesale industry year-end } \\
\text { employees said }\end{array}$ \\
\cline { 2 - 3 } & Capital Input & $\begin{array}{l}\text { Wholesale fixed capital } \\
\text { investment is expressed }\end{array}$ \\
\hline
\end{tabular}

\begin{tabular}{|l|l|l|}
\hline \multirow{2}{*}{$\begin{array}{l}\text { Output } \\
\text { indicators }\end{array}$} & $\begin{array}{l}\text { Main Business } \\
\text { Income }\end{array}$ & $\begin{array}{l}\text { Main business income of } \\
\text { wholesale industry }\end{array}$ \\
\cline { 2 - 3 } & Main Business Profit & $\begin{array}{l}\text { Wholesale business main } \\
\text { business profit }\end{array}$ \\
\hline
\end{tabular}

\subsubsection{The data source}

The research object of this paper is the wholesale industry efficiency analysis of 14 cities in Liaoning Province. The sample is the relevant data of 14 cities in Liaoning Province in 2017, and the relevant data are obtained from the statistical Yearbook of Liaoning Province in 2018.

\section{Empirical Analysis}

By use of Deap2.1 software operations of acquired data, it is concluded that the efficiency of the 14 cities of liaoning province wholesalers and output redundancy, and the corresponding analysis.

\subsection{Analysis of wholesale industry efficiency}

Investment efficiency includes comprehensive technical efficiency, pure technical efficiency and scale efficiency, and comprehensive technical efficiency $=$ pure technical efficiency $\mathrm{x}$ scale efficiency. Comprehensive technical efficiency comprehensively measures the resource allocation ability and resource utilization efficiency of the wholesale industry. Pure technical efficiency reflects the technological progress of the wholesale industry and represents the effective utilization degree of resources. Scale efficiency reflects the gap between the development scale of the wholesale industry and the optimal scale. As can be seen from Table 2, four cities are in the stage of constant return on scale, and ten cities are in the stage of increasing return. From this, it can be seen that the efficiency of wholesale industry in each city of Liaoning province is relatively good.

From the average of 14 cities of liaoning province, pure technical efficiency is highest, at 0.860 , followed by scale efficiency, and 0.763 , the smallest for the comprehensive technical efficiency, is 0.652 , in the stage of scale pay the same city a total of four cities, Shenyang, Dalian, Liaoyang, Panjin set up a file, respectively, the comprehensive technical efficiency, pure technical efficiency and scale efficiency were characterized by 1 , explain the four wholesaling city development is good; The remaining 10 cities, namely Anshan, Fushun, Benxi, Dandong, Jinzhou, Yingkou, Fuxin, Tieling, Chaoyang and Huludao, are all in the stage of increasing return to scale. However, their comprehensive technical efficiency, pure technical efficiency and scale efficiency are all different, so there are various reasons for their unequal return to scale. Among the data of unbalanced cities, the maximum value of comprehensive technical efficiency is 0.848 in Huludao city and 0.299 in Benxi City. The maximum value of pure technical efficiency was 0.895 for Benxi and 0.457 for Yingkou. The maximum scale efficiency was 0.918 in Yingkou, and the minimum was 
0.334 in Benxi. Among the data analysis of the three maximum and minimum efficiency values, Benxi city appeared three times and Yingkou City appeared two times, indicating that Benxi and Yingkou had the largest difference in efficiency, and benxi and Yingkou had the largest room for efficiency improvement. Benxi and Yingkou are the key provinces concerned with the efficiency improvement of wholesale industry.

Table2. Wholesale Efficiency

\begin{tabular}{|l|l|l|l|l|}
\hline & $\begin{array}{c}\text { Integrated } \\
\text { technical } \\
\text { efficiency }\end{array}$ & $\begin{array}{c}\text { Pure } \\
\text { technical } \\
\text { efficiency }\end{array}$ & $\begin{array}{c}\text { Scale } \\
\text { efficiency }\end{array}$ & $\begin{array}{c}\text { scale } \\
\text { state }\end{array}$ \\
\hline Shenyang & 1.000 & 1.000 & 1.000 & - \\
\hline Dalian & 1.000 & 1.000 & 1.000 & - \\
\hline Anshan & 0.473 & 0.517 & 0.914 & irs \\
\hline Fushun & 0.410 & 0.873 & 0.470 & irs \\
\hline Benxi & 0.299 & 0.895 & 0.334 & irs \\
\hline Dandong & 0.526 & 1.000 & 0.526 & irs \\
\hline Jinzhou & 0.616 & 0.743 & 0.829 & irs \\
\hline Yingkou & 0.419 & 0.457 & 0.918 & irs \\
\hline Fuxin & 0.598 & 0.860 & 0.696 & irs \\
\hline Liaoyang & 1.000 & 1.000 & 1.000 & - \\
\hline Panjin & 1.000 & 1.000 & 1.000 & - \\
\hline Tieling & 0.455 & 1.000 & 0.455 & irs \\
\hline Chaoyang & 0.486 & 0.700 & 0.695 & irs \\
\hline Huludao & 0.848 & 1.000 & 0.848 & irs \\
\hline $\begin{array}{l}\text { Mean } \\
\text { value }\end{array}$ & 0.652 & 0.860 & 0.763 & \\
\hline
\end{tabular}

Irs indicates that DMU (decision making unit) is in the stage of increasing returns to scale; indicates that DMU is in the stage of constant reward of scale.

\subsection{Output redundancy analysis}

The output redundancy represents the output increased by the non-effective decision making unit in order to realize DEA effectively. Cities in liaoning province wholesaling output redundancy analysis is as follows: as you can see in table 3, the main business income of liaoning province, the main business profits is output redundancy, among them, the main business income of the four cities have an output redundancy, fuxin output redundancy, return the number of 5994880.939, followed by benxi 1500023.541 , 648722.548 , followed by yingkou the least for fushun 306557.954 , the rest of the 10 cities are no output redundancy, shows that in most cities in liaoning province into high efficiency, input and output in the equilibrium level. Output redundancy of main business profit was generated in two cities, the largest of which was Benxi city 51455.368, followed by Fushun City 16021.679. The remaining 12 Cities in Liaoning Province did not show output redundancy of main business profit, indicating that the input and output of the other cities were relatively balanced. The low input efficiency of the wholesale industry in Fushun and Benxi is caused by the insufficient output of the main business income and the main business profit. The wholesale industry in these two cities should consider increasing the main business income and profit to improve the development efficiency of the wholesale industry. The reason for the low efficiency of the wholesale industry in Yingkou and Fuxin is the low income of the main business, so we should consider increasing the income of the main business.

Table3. Analysis of output redundancy

\begin{tabular}{|l|l|l|}
\hline & Main business income & Main business profit \\
\hline Shenyang & 0.000 & 0.000 \\
\hline Dalian & 0.000 & 0.000 \\
\hline Anshan & 0.000 & 0.000 \\
\hline Fushun & 306557.954 & 16021.679 \\
\hline Benxi & 1500023.541 & 51455.368 \\
\hline Dandong & 0.000 & 0.000 \\
\hline Jinzhou & 0.000 & 0.000 \\
\hline Yingkou & 648722.548 & 0.000 \\
\hline Fuxin & 5994880.939 & 0.000 \\
\hline Liaoyang & 0.000 & 0.000 \\
\hline Panjin & 0.000 & 0.000 \\
\hline Tieling & 0.000 & 0.000 \\
\hline Chaoyang & 0.000 & 0.000 \\
\hline Huludao & 0.000 & 0.000 \\
\hline Mean value & 603584.642 & 4819.789 \\
\hline
\end{tabular}

\section{Conclusions and Suggestions}

\subsection{Conclusion}

\subsubsection{Liaoning province wholesale industry overall efficiency level is low}

The mean value of comprehensive technical efficiency, pure technical efficiency and scale efficiency of all cities in Liaoning province is $0.652,0.860$ and 0.763 , indicating that the overall level of wholesale efficiency in Liaoning province is relatively low. Among them, the mean value of comprehensive technical efficiency is 0.652 , indicating the lowest resource allocation ability and resource use efficiency, redundant input and insufficient output.

\subsubsection{Some cities in Liaoning province have advanced technology}

The comprehensive technical efficiency, pure technical efficiency and scale efficiency of Shenyang, Dalian, Liaoning and Panjin are all 1, indicating that the wholesale industry in some cities of Liaoning province has advanced technical level, sufficient resources, high resource utilization rate and good development environment. 


\subsubsection{Benxi wholesale industry has greater room for growth}

The pure technical efficiency of Benxi is 0.895 , which ranks high, but the scale efficiency is the lowest, only 0.334 , and the comprehensive technical efficiency is the lowest, only 0.299 . The low scale efficiency indicates that the development scale of Benxi's wholesale industry has not reached the optimal scale, and benxi is in the state of increasing scale return, indicating that there is still a large room for growth of the wholesale industry investment in Benxi. If the input volume is appropriately increased, the output will increase in a higher proportion.

By analyzing and calculating the input-output data of the wholesale industry in 14 cities in Liaoning Province, the results show that the efficiency of the wholesale industry in Liaoning province is generally low, but the return to scale is increasing. The efficiency level varies greatly among different cities, and the reasons for the nonDEA effectiveness of the wholesale industry in different cities are different. In addition, except for Anshan and Yingkou, the pure technical efficiency score of China's wholesale industry is all higher than 0.7 , and the comprehensive technical efficiency is generally lower than the pure technical efficiency, indicating that liaoning's wholesale industry should improve the allocation efficiency and use efficiency of resources.

In the two output indicators, the main business income and the main business profit are the reasons for the output shortage. Therefore, the wholesale industry in Liaoning Province should effectively increase the main business income and main business cost, and improve the development efficiency of the wholesale industry.

\subsection{Suggestion}

First, the wholesale industry in Liaoning province should strengthen the sales revenue of commodities, can increase the main business revenue through increasing sales revenue. Second, for some cities, the pure technical efficiency is relatively high, can appropriately increase the input and output, so as to make its development more rapid and better, improve the wholesale industry investment efficiency. Third, Liaoning reduces the cost of wholesale circulation, optimize the circulation path, in order to improve the main business profit. Fourth, Liaoning expands the talent training mechanism of the wholesale industry, provide talents and technical support for the sound development of the wholesale industry, and provide employment opportunities for the public; Fifth, we will give full play to the leading role of technological innovation, and guide and encourage the adoption of new technologies such as cloud computing, the Internet of Things and artificial intelligence in all aspects of the wholesale industry.

\section{References}

1. Ye Meng, Zhu Heliang, Sun Peng. Sequential Changes and Individual Differences of Total Factor Productivity Growth in China's Wholesale and retail
Enterprises -- An empirical Analysis based on DeAMalmquist Index Method [J]. China circulation economy,2017,31(11):112-121.

2. Chen Hua. Spatial Comparative Study on InputOutput Efficiency of China's Wholesale Industry -An Analysis based on super-Efficiency DEA Model [J]. Journal of Heilongjiang Institute of Technology (Comprehensive Edition), 2008,18(10):73-77.

3. Cao Jun. Operation Efficiency analysis of China's Wholesale and Retail Industry based on DEA Model [J]. Business Times,2014(08):4-5.

4. Zhao Xia, Wan Changsong, Xuan Hongyan. Regional Differences in Efficiency of China's circulation Industry under the constraint of low carbon -- A Calculation based on the three-stage DEA model [J]. Journal of Beijing Technology and Business University (Social Science edition), 2008,33(05):4152. 